\title{
SELF-REGULATED LEARNING DAN PERSEPSI DUKUNGAN SOSIAL DENGAN PRESTASI AKADEMIK MAHASISWA FAKULTAS USHULUDDIN IAIN IMAM BONJOL PADANG
}

\author{
Subhan Ajrin Sudirman \\ Jurusan Psikologi Islam IAIN Imam Bonjol Padang \\ Diterima tanggal 14 Pebruari 2015 / Disetujui tanggal 11 Maret 2015
}

\begin{abstract}
This research aimed to examine the correlations between self-regulated learning and social support perception with students academic achievement at Ushuluddin Faculty of State Institute for Islamic Studies Imam Bonjol Padang. This research used purposive sampling technique. The subjects of this research were 150 students. The data were collected by using, (1) The self-regulated learning scale, (2) The social support perception scale, and (3) documentation. The data were analyzed by using multiple regression of SPSS 13.0 for windows. The results of this research are: (1) There is very significant and positive correlation between self-regulated learning and students academic achievement $\left(r=0,325, p<0,001\right.$ and $\left.\mathrm{R}^{2}=0,106\right)$; (2) There is very significant and positive correlation between social support perception and students academic achievement $(r=0,284, p<$ 0,001 and $\left.\mathrm{R}^{2}=0,081\right)$.
\end{abstract}

Kata kunci: self-regulated learning, social support perception and students academic achievement.

\section{Pendahuluan}

Kerangka Pengembangan Pendidikan Tinggi Jangka Panjang (KPPTJP V) 2011 - 2017 adalah suatu rencana strategis pengembangan jangka panjang yang bertujuan menempatkan sistem pendidikan tinggi nasional dengan segala keterbatasannya pada kedudukan yang paling baik di masa depan agar mampu menanggapi tantangan yang dihadapi secara efektif (Brodjonegoro, dkk., 2001). KPPTJP 2011 - 2017 berkaitan dengan tantangan masa depan yang dihadapi bangsa Indonesia. Gambaran mengenai suatu hal yang harus dihadapi dalam era ilmu pengetahuan dan tekhnologi serta globalisasi menunjukkan mutlaknya mutu lulusan pendidikan tinggi. Kenyataannya kualitas sumber daya manusia Indonesia sangat rendah dibandingkan negara-negara lain. Harian Kompas (03 Januari 2013) mengungkapkan bahwa berdasarkan Human Development Index, kualitas sumber daya manusia (SDM) Indonesia saat ini berada pada peringkat ke 121 dari 187 negara di dunia. Sementara itu Singapura berada di urutan 23, Brunei di urutan 30 dan Malaysia pada urutan 66. Hal ini, mengindikasikan rendahnya kualitas sumber daya manusia Indonesia. Rendahnya SDM ini sangat terkait dengan mutu pendidikan di Indonesia yang belum optimal.

Peningkatan kualitas SDM dapat dilakukan melalui peningkatan kualitas pendidikan. Kualitas pendidikan dapat dilihat dari nilai tambah yang dihasilkan oleh lembaga pendidikan, baik produk dan jasa maupun pelayanan yang mampu bersaing di lapangan kerja yang ada dan 
yang diperlukan. Senada dengan hal tersebut Djojonegoro (dalam Kumara, 2000) mengatakan bahwa sumber daya manusia berkualitas yang diharapkan dapat dihasilkan oleh dunia pendidikan di Indonesia paling tidak memenuhi empat kompetensi, yaitu: a) kompetensi akademik, b) kompetensi profesional, c) kompetensi nilai dan sikap, d) kompetensi untuk menghadapi perubahan.

Perguruan Tinggi merupakan suatu lembaga pendidikan tinggi yang menjadi harapan untuk dapat diandalkan sebagai sarana pembentuk manusia-manusia Indonesia yang berkualitas dan profesional yang siap menghadapi tantangan-tantangan globalisasi di masa depan. Perguruan tinggi diharapkan mampu menghasilkan tenaga profesional yang memiliki kinerja yang baik di lingkungan kerja maupun lingkungan masyarakat. Tujuan diselenggarakannya pendidikan tinggi sendiri adalah untuk mempersiapkan mahasiswa menjadi "tenaga-tenaga ahli" dalam berbagai bidang ilmu dan seni, sehingga para lulusan perguruan tinggi dapat menjadi sumber daya insani pembangunan yang berkualitas. Hal ini sangat penting mengingat mahasiswa merupakan bagian dari generasi muda yang kelak menjadi tumpuan masyarakat, bangsa dan pembangunan masa datang. Oleh karena itu dalam menempuh pendidikan di perguruan tinggi para mahasiswa diharapkan untuk dapat memanfaatkan kesempatan dan kemampuannya secara optimal agar dapat mencapai prestasi akademik yang optimal pula.

Prestasi akademik adalah hasil yang diperoleh dari kegiatan belajar, dengan demikian prestasi akademik dapat pula dikatakan sebagai tolok ukur berhasil atau tidaknya proses belajar. Bila prestasi akademik yang diperoleh mahasiswa tinggi, maka diasumsikan bahwa kegiatan belajar yang telah dilaksanakan berhasil, demikian sebaliknya bila prestasi akademik yang diperoleh rendah, maka diasumsikan bahwa kegiatan belajar yang telah dilaksanakan belum berhasil. Prestasi akademik mahasiswa yang optimal selain sebagai tolok ukur berhasil atau tidaknya suatu proses belajar, prestasi yang optimal juga berperan dalam beberapa hal antara lain, a) memberikan kepuasan status sosial, harga diri (prestise), b) kepuasan ekonomi serta kepuasan-kepuasan yang lain, dan c) prestasi yang optimal mencerminkan kualitas suatu bangsa (Thabrany, 1997). Seorang mahasiswa yang memperoleh prestasi akademik yang tinggi diasumsikan memiliki kepercayaan diri yang tinggi, ia akan lebih mudah diterima dan diakui oleh lingkungannya sehingga dapat memberikan kepuasan sosial. Pada usia remaja prestasi yang baik dapat memberikan kepuasan pribadi dan ketenaran. Prestasi yang baik dapat menimbulkan harga diri dalam pandangan teman sebayanya (Hurlock, 2002). Prestasi yang tinggi dapat memberikan kepuasan ekonomi bagi mahasiswa. Mahasiswa yang memiliki prestasi akademik yang tinggi seringkali memperoleh bantuan dana beasiswa ketika menempuh pendidikan di perguruan tinggi. Demikian pula bila mahasiswa berhasil lulus dengan prestasi akademik yang tinggi akan memiliki kemudahan dalam memperoleh lapangan pekerjaan. Selain memberikan kepuasan sosial dan ekonomi sebagai individu, tingginya mutu para lulusan lembaga pendidikan tinggi akan menciptakan sumber daya manusia serta dapat mencerminkan kualitas suatu bangsa yang tinggi pula. Sebagaimana diungkapkan oleh Widianto (dalam Kompas, 1 Mei 2013) bahwa untuk membentuk manusia-manusia Indonesia yang bermutu adalah dengan menjadikan prestasi sebagai tolok ukur dari mutu manusia Indonesia. Berdasarkan alasan-alasan yang telah diuraikan di atas, maka persoalan prestasi berkaitan dengan bidang pendidikan, dalam hal ini prestasi akademik merupakan hal yang penting. 
Banyak faktor yang turut mempengaruhi keberhasilan maupun kegagalan mahasiswa dalam menempuh pendidikannya di perguruan tinggi (Suryabrata, 1998). Secara umum, faktor yang mempengaruhi prestasi akademik mahasiswa adalah faktor internal, yakni faktor yang berasal dari dalam diri mahasiswa dan faktor eksternal yang merupakan faktor dari luar diri mahasiswa. Faktor eksternal mahasiswa yakni terdiri dari; lingkungan keluarga, teman-teman dan lingkungan akademik juga turut mempengaruhi proses akademik mahasiswa. Usman dan Setyawati (1993) individu yang belajar akan menerima pengaruh dari: a) lingkungan keluarga, b) lingkungan masyarakat, c) lingkungan akademik, dan d) lingkungan kelompok.

Proses menempuh pendidikan di lembaga perguruan tinggi tentu berbeda dengan lembaga pendidikan sebelumnya. Di perguruan tinggi, materi belajar yang diberikan pada mahasiswa lebih luas dan kompleks dibandingkan materi pelajaran yang diberikan di sekolah menengah. Dengan demikian, mahasiswa di perguruan tinggi dituntut untuk memiliki kemampuan mengatur diri dan perilakunya secara aktif dan mandiri dalam aktivitas belajarnya demi keberhasilan akademiknya. Sebagaimana ungkapan Gie (1994) bahwa mahasiswa hendaknya melakukan belajar (studi) yang dilakukan dengan penuh semangat dan menggunakan kesempatan yang ada dengan sebaik-baiknya, barulah mahasiswa dapat meraih sukses di perguruan tinggi. Pada kenyataannya, banyak di antara mahasiswa tidak memiliki kemampuan-kemampuan dalam belajar yang efektif sebagaimana seharusnya. Hal ini disebabkan karena mahasiswa khususnya yang berada pada semester-semester awal masih memiliki perilaku-perilaku belajar sebagaimana ketika berada di sekolah menengah. Mahasiswa pada umumnya belum memiliki kesiapan dan kemampuan untuk mengatur aktivitas belajarnya secara efektif dan mandiri. Kebanyakan mahasiswa melakukan aktivitas belajar secara santai, hanya tampak sibuk menjelang waktu ujian dan belajar secara "SKS" (sistem kebut semalam), pada waktu-waktu kuliah yang kosong umumnya mereka berkumpul dan mengobrol dengan teman-temannya dan tidak terlihat bersemangat untuk membaca buku sebanyak-banyaknya dan berusaha memperluas pengetahuan ilmiah seluas mungkin. Perilaku-perilaku di atas tentu tidak efektif dan menghambat keberhasilan mahasiswa di perguruan tinggi.

Self-regulated learning merupakan faktor internal yang penting dalam mengoptimalkan prestasi akademik mahasiswa. Gie (1995) menyimpulkan bahwa terdapat beberapa syarat bagi mahasiswa untuk mencapai kesuksesan salah satunya adalah pengaturan diri, yakni pengaturan sebaikbaiknya terhadap pikiran, tenaga, waktu dan semua sumber daya lainnya dalam belajarnya. Selfregulated learning atau disebut dengan pengelolaan diri adalah suatu strategi yang mengacu pada kemampuan individu untuk mengatur dirinya dalam proses belajar, dengan mengikutsertakan kemampuan metakognisi, motivasi dan perilaku aktif (Zimmerman dan Schunk dalam Ablard dan Lipzchultz, 1998). Kemampuan metakognisi mengacu pada seberapa besar pengetahuan individu mengenai dirinya dalam merencanakan, mengorganisasi atau mengatur, menginstruksikan diri, memonitor dan mengevaluasi diri dalam belajar. Motivasi merupakan pendorong (drive) yang ada pada diri individu yang mencakup persepsi terhadap efikasi diri, kompetensi dan otonomi yang dimiliki dalam aktivitas belajar. Perilaku merupakan upaya individu untuk mengatur diri, menyeleksi dan memanfaatkan lingkungan maupun menciptakan lingkungan yang mendukung aktivitas belajar. Dengan demikian, Individu memiliki otonomi dalam dirinya untuk memilih, menyusun dan menciptakan lingkungan sosial dan fisik seimbang 
dalam mencapai belajar yang optimal. Sebagaimana Peverly, dkk. (2003) menggambarkan bahwa individu yang melakukan self-regulated learning adalah individu yang memiliki pengetahuan dan tujuan strategis serta memiliki kemandirian untuk mengerahkan kemampuannya secara efektif dalam belajar.

Melalui strategi self-regulated learning diasumsikan mahasiswa mampu menempuh proses pendidikan dan prestasi akademik dengan optimal karena dalam strategi self-regulated learning, mahasiswa memiliki kemampuan mengorganisasikan diri terhadap tugas-tugas akademik yang dibebankan dengan efektif sebagai upaya untuk mengoptimalkan performansi akademiknya (Butler dan Winne, 1995).

Selain pengaruh faktor internal dalam proses dan keberhasilan akademik, mahasiswa juga dipengaruhi oleh faktor eksternal. Faktor eksternal yang berasal dari lingkungan sosial dan non sosial mahasiswa turut berpengaruh terhadap prestasi akademik amahasiswa. Lingkungan di sekitar individu seperti, lingkungan keluarga, lingkungan masyarakat, lingkungan akademik, dan lingkungan kelompok memiliki pengaruh terhadap keberhasilan individu dalam belajar (Usman dan Setyawati, 1993). Bila lingkungan sekitar memberikan dukungan yang positif maka akan mendukung proses dan keberhasilan akademik mahasiswa, sebaliknya bila lingkungan di sekitar tidak memberikan dukungan yang positif maka akan menghambat mahasiswa untuk meraih prestasi akademik yang optimal. Pentingnya dukungan ini, mengingat mahasiswa berada pada fase remaja akhir menuju fase dewasa awal dengan rentang usia antara 19 - 21 tahun. Pada usia ini seseorang dapat dikatakan sebagai individu yang dewasa dan selanjutnya dianggap telah mempunyai sikap mandiri, memiliki tanggung jawab terhadap perbuatannya serta telah mampu memilih apa yang menjadi pilihannya (Mönks, Knoers dan Haditono, 2002). Meskipun individu telah dianggap dewasa, ada beberapa hal yang tidak dapat dihadapinya sendiri sehingga membutuhkan bantuan orang lain. Hal ini, berkaitan dengan ciri perkembangan yang terjadi pada masa remaja yang merupakan periode perubahan. Perubahan-perubahan yang pada umumnya dialami remaja, antara lain; meningkatnya emosi, perubahan tubuh, minat dan peran yang diharapkan, perubahan nilai-nilai seiring dengan perubahan minat dan pola perilaku, timbulnya sikap ambivalen terhadap setiap perubahan. Artinya, di satu sisi remaja menginginkan dan menuntut kebebasan, tetapi merasa takut bertanggung jawab akan akibatnya dan meragukan kemampuan dirinya untuk dapat mengatasi tanggung jawab tersebut (Hurlock, 2002).

Persepsi dukungan sosial merupakan faktor eksternal yang diasumsikan dapat memberikan pengaruh positif yang mendukung optimalnya prestasi akademik mahasiswa. Persepsi dukungan sosial yang dimaksud dalam penelitian ialah penilaian atau interpretasi mahasiswa terhadap dukungan sosial yang diterima dari orang-orang terdekatnya. Dukungan sosial adalah pertolongan yang diperoleh individu melalui hubungan interpersonalnya dengan individu lain yang berada di sekitarnya baik dalam bentuk material maupun non material. Bentuk dukungan sosial yang dapat diterima mahasiswa yakni, a) dukungan emosional, b) dukungan penghargaan (appraisal), c) dukungan informasional, dan d) dukungan instrumental (House dan Kahn dalam Cohen dan Syme, 1985). Dukungan emosional adalah dukungan dalam bentuk penghargaan, kasih sayang, kepercayaan, perhatian dan perasaan didengarkan dalam memecahkan masalah yang dihadapi, baik masalah pribadi atau masalah yang berkaitan dengan studi. Dukungan penghargaan (appraisal) adalah dukungan dalam bentuk penilaian, umpan balik dan 
perbandingan sosial dalam upaya mendukung perilakunya dalam aktivitas akademik maupun kehidupan sosial. Dukungan informasional adalah dukungan yang diterima individu dalam bentuk informasi, nasihat dan saran yang berguna untuk mempermudah individu dalam menjalani proses akademiknya di perguruan tinggi. Dukungan instrumental adalah dukungan yang diterima individu melalui waktu, uang, alat, tenaga dan memodifikasi lingkungan yaitu tersedia untuk menolong individu ketika menghadapi masalah dalam belajarnya. Selain dukungan instrumental berupa pemenuhan materiil dan sarana-prasarana dalam belajar, mahasiswa yang menempuh pendidikan di perguruan tinggi tidak jarang mengalami gangguan psikologis. Gangguan psikologis, misalnya stres dengan materi kuliah yang kompleks, hubungan dengan teman dan lain sebagainya dapat mengganggu konsentrasinya dalam belajar. Adanya dukungan yang diberikan oleh orang-orang terdekatnya diharapkan mampu membantu meredakan dan menyelesaikan permasalahan yang dihadapi.

\section{Prestasi Akademik Mahasiswa}

Istilah prestasi akademik kadang-kadang digunakan secara berganti-ganti dengan istilah prestasi belajar, tetapi kedua istilah ini sebenarnya mempunyai makna yang sama (Moedjanto, 1981). Istilah prestasi belajar mengandung makna yaitu hasil yang diperoleh dari aktivitasaktivitas belajar berupa penguasaan pengetahuan atau keterampilan, lazimnya ditunjukkan dengan nilai tes atau angka nilai. Prestasi akademik adalah hasil belajar yang diperoleh dari kegiatan akademik yang bersifat kognitif dan biasanya ditentukan melalui pengukuran dan penilaian (Tim Penyusun Kamus Pusat Pembinaan dan Pengembangan Bahasa, 2002). Pada umumnya, istilah prestasi belajar digunakan untuk siswa sekolah di SD, SMP, SMA, sedangkan prestasi akademik digunakan untuk mahasiswa di lembaga perguruan tinggi.

Kimble (dalam Hergenhann dan Olson, 1997) bahwa belajar adalah suatu bentuk perilaku yang terjadi sebagai latihan yang dilakukan individu dan secara potensial bersifat permanen. Jika rumusan belajar yang dikemukakan oleh Kimble ditelaah lebih lanjut, maka tampak adanya beberapa keadaan yang memberikan ciri dari makna belajar. Pertama, belajar ditandai oleh adanya perubahan tingkah laku (change in behavior). Ini berarti bahwa hasil dari belajar hanya dapat diamati dari tingkah laku yaitu adanya perubahan tingkah laku, dari tidak tahu menjadi tahu, dari tidak terampil menjadi terampil. Kedua, perubahan tingkah laku tersebut relatif permanen. Ini diartikan bahwa perubahan tingkah laku yang terjadi pada waktu tertentu akan tetap, akan berubah bila mengalami proses belajar berikutnya. Ketiga, perubahan tingkah laku itu tidak harus nampak secara langsung mengikuti pengalaman belajar. Telah dikatakan sebelumnya bahwa belajar ditandai oleh adanya perubahan tingkah laku, namun perlu diperhatikan bahwa perubahan tingkah laku tersebut tidak secara langsung nampak segera mengikuti pengalaman belajar. Keempat, perubahan tingkah laku tersebut merupakan hasil dari pengalaman dan latihan. Ini berarti bahwa perubahan tingkah laku itu tidak terjadi dengan sendirinya atau terjadi tanpa pengaruh dari luar. Adanya keadaan yang mempengaruhi merupakan suatu yang dialami individu yang memungkinkan terjadinya perubahan tingkah laku. Kelima, pengalaman atau latihan itu harus disertai atau mengandung sesuatu yang memperkuat. 


\section{Faktor-faktor yang Mempengaruhi Prestasi Akademik Mahasiswa}

Berbagai faktor yang dapat mempengaruhi prestasi akademik. Winkel (1996) mengemukakan beberapa faktor yang mempengaruhi proses dan prestasi akademik, antara lain: 1) karakteristik individu, mencakup karakteristik psikis dan fisik; 2) pengajaran, mencakup materi pelajaran dan keterampilan mengajar; 3) bahan atau materi yang akan dipelajari, mencakup jenis materi, tingkat kesukaran dan kompleksitas; 4) media pengajaran, mencakup jenis media yang dipakai dan penggunaannya; 5) karakteristik sekolah, gedung dan fasilitas belajar; dan 6) lingkungan dan situasi, meliputi lingkungan alam seperti suhu, musim dan iklim. Secara umum, faktor-faktor yang mempengaruhi prestasi akademik dapat dibedakan menjadi dua macam, yakni; a) faktor internal, yakni keadaan/kondisi jasmani dan rohani individu, dan b) faktor eksternal, yakni kondisi lingkungan di sekitar individu (Suryabrata, 1998; dan Syah, 2003).

\section{Self-regulated Learning}

Self-regulated learning adalah faktor internal individu yang diperkirakan memiliki pengaruh terhadap peningkatan prestasi akademik mahasiswa. Self-regulated learning merupakan strategi yang diterapkan individu dalam aktivitas belajarnya.

Konsep tentang self-regulation atau pengelolaan diri berawal dari ide utamanya Bandura (dalam Miller dan Byrnes, 2001) bahwa individu tidak dapat secara efektif beradaptasi terhadap lingkungannya selama mampu membuat kemampuan kontrol pada proses psikologi dan perilakunya. Berdasarkan konsep tersebut self-regulation berkaitan dengan pembangkitan diri baik pikiran, perasaan serta tindakan yang direncanakan dan adanya timbal balik yang disesuaikan pada pencapaian tujuan personal atau dengan kata lain self-regulation berhubungan dengan metakognitif, motivasi, dan perilaku yang berpartisipasi aktif untuk mencapai tujuan personal (Zimmerman, 1989). Menurut Schunk dan Ertmer (1999) self-regulation adalah proses yang berputar dan terus berubah selama proses belajar. Gambaran proses berputar ini dilukiskan oleh Zimmerman (dalam Schunk dan Ertmer, 1999) dengan tiga tahap model self-regulation. Pertama, forethought phase (pemikiran sebelumnya) yaitu performansi aktual yang mendahului dan berkenaan dengan proses pengumpulan langkah untuk suatu tindakan. Kedua, performance (volitional) control phase yaitu mencakup proses yang terjadi sebelum belajar dan mempengaruhi perhatian dan perilaku. Ketiga, selama self-reflection phase terjadi setelah performansi individu merespon pada usahanya dalam upaya pencapaian tujuannya.

Pengertian self-regulated learning lebih lanjut dijabarkan oleh Purdie, dkk. (1996) bahwa teori self-regulated learning memfokuskan perhatian pada mengapa dan bagaimana individu berinisiatif dan mengontrol diri terhadap belajar mereka. Hal ini diperkuat oleh Shu-Shen Shih (2002) bahwa efektivitas dalam penggunaan strategi self-regulated learning memegang peranan penting dalam meningkatkan persepsi kontrol diri dalam aktivitas belajar.

\section{Faktor-faktor yang Memengarubi Self-regulated Learning}

Bandura (dalam Zimmerman, 1989) mengatakan bahwa self-regulated learning mengacu pada tingkatan bagaimana individu dapat menggunakan dirinya untuk mengatur strategi dalam berperilaku dan mengatur lingkungan belajarnya. 
Menurut teori sosial-kognitif, ada tiga hal yang mempengaruhi self-regulated learning, yaitu: a. Individu (self), faktor individu meliputi:

1) Pengetahuan yang dimiliki individu. Semakin banyak dan beragam pengetahuan yang dimiliki individu akan semakin membantu individu dalam melakukan self-regulated learning.

2) Tingkat kemampuan metakognisi. Semakin tinggi tingkat metakognisi yang dimiliki, semakin membantu pelaksanaan self-regulated learning dalam diri individu.

3) Tujuan yang ingin dicapai. Hasil yang diperoleh dan kompleksitas tujuan yang ingin diraih dalam aktivitas belajar, semakin besar kemungkinan individu melakukan selfregulated learning.

b. Perilaku, faktor perilaku mengacu pada upaya individu menggunakan kemampuan yang dimiliki. Semakin besar dan optimal upaya yang dilakukan individu dalam mengatur dan mengorganisasikan proses belajar akan meningkatkan self-regulated learning pada diri individu. Bandura (1977) menyatakan dalam perilaku ini, ada tiga tahap yang berkaitan dengan selfregulation yaitu:

1) self-observation yang berkaitan dengan respon individu, yaitu tahap individu melihat ke dalam dirinya dan performansinya;

2) self-judgment merupakan tahap individu membandingkan informasi standar yang telah dilakukannya dengan standar atau tujuan yang sudah dibuat dan ditetapkan individu. Melalui upaya membandingkan performansi dengan standar atau tujuan yang ditetapkan, individu dapat melakukan evaluasi atas performansi yang telah dilakukan dengan mengetahui letak kelemahan atau kekurangan performansinya;

3) self-reaction merupakan tahap yang mencakup proses individu dalam menyesuaikan diri dan rencana untuk mencapai tujuan atau standar yang telah dibuat dan ditetapkan.

c. Lingkungan, menurut Bandura (dalam Zimmerman, 1989) lingkungan memiliki peran terhadap pengelolaan diri dalam belajar, yaitu sebagai tempat individu melakukan aktivitas belajar dan memberikan fasilitas kepada aktivitas belajar yang dilakukan, apakah fasilitas tersebut cenderung mendukung atau menghambat aktivitas belajar khususnya self-regulated learning.

\section{Persepsi Dukungan Sosial}

Young (1956) mengemukakan bahwa persepsi merupakan aktivitas dari mengindera, menginterpretasikan dan memberikan penilaian terhadap objek-objek fisik maupun objek-objek sosial dan penginderaan tersebut tergantung pada stimulus yang ada di lingkungannya. Menurut Solso (1995) persepsi merupakan suatu proses yang menggunakan pengetahuan sebelumnya untuk mengumpulkan dan menginterpretasikan stimulus yang ditangkap oleh indera. Persepsi menggabungkan dunia luar (stimulus sensori) dan pengalaman sebelumnya (inner word). Sternberg (1999) menguraikan bahwa persepsi merupakan pengalaman tentang objek, peristiwa atau hubungan-hubungan yang diperoleh dengan menyimpulkan informasi dan menafsirkan pesan. Persepsi merupakan proses pemberian makna pada stimuli inderawi (sensory stimulus). Crow dan Crow (1973) menyatakan bahwa persepsi adalah proses pengorganisasian dan penginterpretasian data sensoris yang didasari oleh hasil pengalaman sebelumnya. 
Sesuai dengan teori mengenai persepsi yang dikemukakan para ahli tersebut, maka dapat disimpulkan bahwa persepsi sebagai representasi mengenai stimulus-stimulus di luar dengan melibatkan pengetahuan sebelumnya dan merupakan hasil pengolahan mental. Persepsi merupakan proses transaksi penilaian terhadap suatu objek, situasi, peristiwa, orang lain berdasarkan pengalaman masa lampau, sikap, harapan dan nilai yang ada pada diri individu. Objek persepsi dalam penelitian ini adalah dukungan sosial yang diperoleh mahasiswa dari lingkungan sekitarnya.

\section{Hubungan Self-regulated Learning dengan Prestasi Akademik Mahasiswa}

Proses belajar yang ditempuh mahasiswa di perguruan tinggi menjadi lebih luas dan kompleks. Hal ini, menuntut mahasiswa untuk mampu menjalankan proses belajarnya dengan baik. Ada banyak faktor yang mempengaruhi proses belajar, di antara faktor tersebut berperan untuk meningkatkan prestasi akademik ataupun sebaliknya mengahambat prestasi akademik mahasiswa. Faktor yang dapat mempengaruhi tinggi dan rendahnya prestasi akademik mahasiswa adalah faktor internal individu. Faktor internal seringkali menjadi penghambat dan pendukung keberhasilan individu. Individu yang memiliki kemampuan dalam mengatur perilaku yang efektif dalam belajar dapat mendukung keberhasilannya. Sebaliknya individu yang tidak mampu mengatur perilaku belajarnya, tidak memiliki kemauan yang kuat untuk belajar akan menemui kegagalan dan proses belajarnya.

Self-regulated learning memiliki peranan penting dalam pencapaian hasil akademik yang optimal. Sebagaimana disimpulkan oleh Gie (1995) bahwa terdapat beberapa syarat bagi mahasiswa untuk mencapai kesuksesan akademik salah satunya adalah pengaturan diri, yakni pengaturan sebaik-baiknya terhadap pikiran, tenaga, waktu dan semua sumber daya lainnya dalam belajarnya. Mahasiswa yang menerapkan self-regulation dalam belajarnya memiliki kemampuan untuk mengatur dirinya dengan melibatkan kemampuan metakognisi, motivasi dan perilaku yang aktif. Kegagalan dalam mengelola diri akan berimbas pada kejahatan, prestasi yang menurun dan problem-problem sosial lainnya (Baumeister dan Heatherton, 1996). Pengaruh self-regulated learning terhadap prestasi belajar dapat pula dilihat dalam penelitianpenelitian sebelumnya, antara lain penelitian yang dilakukan oleh Purwanto (1996). Purwanto (1996) dalam penelitiannya menyimpulkan bahwa ada hubungan antara self-regulated learning dengan prestasi akademik. Hal ini, menunjukkan bahwa self-regulated learning memiliki pengaruh terhadap prestasi akademik yang optimal. Penelitian yang lain dilakukan oleh Sunawan (2003) ditemukan bahwa individu yang menerapkan self-regulated learning dalam belajar bidang studi matematika memperoleh hasil belajar yang lebih tinggi dibandingkan individu yang tidak menerapkan self-regulated learning dalam matematika. Dengan demikian dapat disimpulkan bahwa self-regulated learning memiliki peran penting dalam meningkatkan prestasi akademik mahasiswa di perguruan tinggi.

\section{Hubungan Persepsi Dukungan Sosial dengan Prestasi Akademik Mahasiswa}

Mahasiswa sebagai individu yang baru menanjak dari remaja ke dewasa mengalami suatu masalah antara adanya tuntutan untuk terikat dengan keluarga dan kebutuhan kemandirian diri, mengurus dirinya dan keinginan mempunyai otoritas pribadi untuk bertanggung jawab 
dan memutuskan segala permasalahan terhadap dirinya sendiri (Meichati, 1976). Dukungan sosial sangat mungkin untuk memberikan sumbangan terhadap kestabilan psikologis seseorang seperti halnya melindungi seseorang dari situasi-situasi yang genting (Hersen, 1987).

Dukungan sosial merupakan tindakan menolong yang diperoleh melalui hubungan interpersonal dengan orang di sekitar individu yang memiliki arti bagi individu tersebut. Untuk membantu mahasiswa dalam mencapai hasil akademik yang optimal sesuai kemampuannya, salah satu upaya yang dapat dilakukan adalah dengan memanfaatkan orang di mana individu itu berada dengan pemberian dukungan sosial. Seorang mahasiswa dalam menempuh studinya di perguruan tinggi tidak akan terpisah dari dukungan sosial orang-orang di sekitarnya, terutama dukungan materiil, sarana belajar, kasih sayang, penghargaan dan sebagainya. Hubungan interpersonal yang akrab antara mahasiswa dengan teman mahasiswa lainnya turut berperan dalam proses akademik mahasiswa. Sebagaimana dikemukakan oleh Singer (1991) bahwa hubungan persahabatan memungkinkan mahasiswa mengembangkan kemampuan intelektual dalam iklim belajar yang diwarnai suasana tenang dan kebersamaan, daya tangkapnya akan lebih cepat dan daya ingatnya bertambah baik. Sebaliknya, menurut Conger (1977) bila individu tidak memiliki hubungan interpersonal yang akrab dan mengalami kesulitan dalam melakukan hubungan interpersonal dengan kelompok akademiknya akan mengakibatkan rendah pula prestasi akademiknya.

\section{Desain Penelitian}

Untuk memperoleh data yang relevan dan akurat, maka diperlukan suatu metode pengumpulan data. Metode pengumpulan data dalam penelitian ini, digunakan skala atau angket untuk variabel self-regulated learning dan dukungan sosial sebagai proses pengumpulan data kuantitatif. Angket adalah suatu alat pengumpul data yang berupa sejumlah pernyataan yang harus dijawab oleh subjek yang menjadi sasaran atau responden penelitian.

Penggunaan angket sebagai salah satu alat pengumpulan data didasarkan pada pertimbangan sebagaimana yang dikemukakan oleh Hadi (2000) sebagai berikut: (1) subjek adalah orang yang paling tahu tentang dirinya sendiri; (2) apa yang dinyatakan oleh subjek adalah benar dan dapat dipercaya; (3) interpretasi subjek tentang pernyataan-pernyataan yang diajukan kepadanya adalah sama dengan apa yang dimaksud oleh peneliti. Kelebihan lain dari metode angket ini, dikemukakan oleh Walgito (1994) yaitu: (a) metode ini merupakan metode yang praktis; (b) dalam waktu yang singkat dapat memperoleh data yang banyak; (c) hemat, dengan menggunakan angket, tenaga yang digunakan sedikit; dan (d) orang dapat menjawab dengan leluasa dan tidak dipengaruhi oleh teman-teman yang lainnya. Selain menggunakan angket, dalam penelitian ini juga menggunakan dokumentasi untuk memperoleh data IPK untuk variabel prestasi akademik.

\section{Hasil Penelitian dan Pembahasan}

Penelitian ini terdiri dari 150 mahasiswa/i sebagai responden. Data yang dianalisis diperoleh dengan cara menyebarkan skala self-regulated learning untuk memperoleh data self-regulated learning, skala persepsi dukungan sosial untuk memperoleh data persepsi dukungan sosial dan dokumentasi IPK untuk mengetahui prestasi akademik mahasiswa. 
Data yang diperoleh dianalisis dengan teknik korelasi regresi ganda untuk mencari hubungan self-regulated learning dan persepsi dukungan sosial dengan prestasi akademik mahasiswa melalui program SPSS 13.0 for Windows.

Hasil analisis data menunjukkan bahwa hipotesis pertama yang menyatakan adanya hubungan antara self-regulated learning dengan prestasi akademik mahasiswa terbukti kebenarannya. Hubungan positif antara kedua variabel self-regulated learning dan prestasi akademik mahasiswa ini menunjukkan bahwa hubungan berjalan searah, artinya meningkatnya prestasi akademik mahasiswa diikuti dengan kenaikan skor self-regulated learning. Kekuatan hubungan antara variabel self-regulated learning dan prestasi akademik mahasiswa ini ditunjukkan oleh $\mathrm{r}$ sebesar $0,325, \mathrm{p}<$ 0,001 dan sumbangan efektif self-regulated learning terhadap prestasi akademik mahasiswa sebesar $10,6 \%$. Ini berarti, semakin tinggi self-regulated learning mahasiswa akan semakin tinggi pula prestasi akademiknya.

Hasil penelitian ini merupakan suatu bukti bahwa self-regulated learning dapat meningkatkan prestasi akademik mahasiswa. Peningkatan yang diberikan meskipun hanya sebesar 10,6\% dan $89,4 \%$ lainnya dipengaruhi oleh faktor lain. Penemuan ini mendukung penelitian yang dilakukan oleh Salisbury-Glennon, dkk. (2001) bahwa kelompok individu yang memiliki prestasi tinggi menggunakan strategi self-regulated learning yang tinggi dibandingkan individu lain yang memiliki prestasi rendah di sekolah. Artinya, strategi self-regulated learning dapat membantu individu dalam memperoleh prestasi yang tinggi sedangkan individu yang tidak menggunakan strategi selfregulated learning memiliki prestasi yang lebih rendah. Individu yang gagal dalam menerapkan self-regulation akan berakibat pada kejahatan, prestasi yang rendah, kehamilan muda, kecanduan obat-obatan, dan kekerasan domestik di sekitar problem sosial (Baumeister dan Heatherton, 1996).

Menurut Zimmerman (1989) individu dengan self-regulated learning akan memiliki perilaku yang selalu mengacu pada kemampuan metakognitif, motivasi dan perilaku. Bagaimana seseorang merencanakan, mengatur, mengontrol diri terhadap motivasi, serta menyusun atau memanfaatkan lingkungan yang mendukung aktivitas belajarnya.

Setiap individu memiliki self-regulated learning yang berbeda-beda, ada yang memiliki selfregulated learning rendah dan ada yang tinggi. Melihat hasil pengkategorisasian subjek yang diperoleh dalam penelitian ini, self-regulated learning mahasiswa secara umum berada pada klasifikasi sedang sebesar 44\%. Hasil ini menginformasikan bahwa mahasiswa cukup sering menerapkan self-regulated learning dalam aktivitas belajar mereka. Bagi individu yang memiliki self-regulated learning tinggi mampu mengelola dan mengembangkan pengetahuan dan perilaku untuk tetap konsisten dan mengarah kepada performansi akademik yang baik. Hal ini karena individu mampu mengorganisasikan dan mengontrol diri sesuai dengan perencanaan dan tujuan yang ingin dicapai. Schunk dan Zimmerman (dalam Wolters, 1998) mengemukakan bahwa karakteristik yang dimiliki oleh self-regulated learners yaitu individu yang memiliki kemampuan untuk, 1) aktif dalam mengatur aktivitas belajarnya dengan berbagai cara. Pintrich, Garcia, dan Schunk (dalam Wolters, 1998) menambahkan bahwa self-regulated leaners secara teoritis adalah individu yang memiliki simpanan metakognisi yang besar dan strategi metakognitif yang diterapkan pada saat dibutuhkan khususnya dalam menyelesaikan tugas-tugas akademiknya. Sedangkan Purdie, dkk. (1996) menyebutkan karakteristik yang dimiliki oleh self-regulated learners 
yaitu individu yang memiliki tujuan, strategi dan keteguhan dalam belajar, serta memiliki kemampuan untuk mengevaluasi aktivitas belajarnya dikaitkan dengan tujuan yang telah dibuat dalam belajar. Mahasiswa yang mempunyai self-regulated learning yang tinggi akan mampu mengarahkan dan meregulasikan perilaku berdasar pada motivasi, perilaku dan metakognisinya. Mahasiswa yang berada pada semester awal (semester V) di fakultas Ushuluddin masih berada pada masa transisi. Mahasiswa masih memiliki perilaku belajar ketika berada di sekolah menengah sehingga mereka belum memiliki kesiapan belajar secara mandiri sebagaimana dibutuhkan di perguruan tinggi. Individu yang memiliki self-regulated learning rendah tidak mampu mengorganisasikan dan mengatur diri sendiri, sehingga mahasiswa dengan self-regulated learning yang rendah cenderung memiliki perilaku belajar yang asal-asalan, tidak memiliki perencanaan dan tujuan yang jelas dalam belajar. Kontrol terhadap aktivitas belajar sangat kurang sehingga berakibat pada kegagalan dalam memperoleh prestasi akademik yang optimal.

Hipotesis kedua yang menyatakan adanya hubungan antara persepsi dukungan sosial dengan prestasi akademik mahasiswa terbukti kebenarannya. Hubungan positif antara kedua variabel persepsi dukungan sosial dan prestasi akademik mahasiswa ini menunjukkan bahwa hubungan berjalan searah, artinya meningkatnya prestasi akademik mahasiswa diikuti dengan kenaikan skor persepsi dukungan sosial.

Kekuatan hubungan antara variabel persepsi dukungan sosial dan prestasi akademik mahasiswa ini ditunjukkan oleh $\mathrm{r}$ sebesar 0,284, $\mathrm{p}<0,001$ dan sumbangan efektif persepsi dukungan sosial terhadap prestasi akademik mahasiswa sebesar $8,1 \%$. Ini berarti, semakin tinggi persepsi dukungan sosial mahasiswa akan semakin tinggi pula prestasi akademiknya.

Hasil penelitian ini merupakan suatu bukti bahwa persepsi dukungan sosial dapat meningkatkan prestasi akademik mahasiswa. Peningkatan yang diberikan meskipun hanya 8,1\% dan 91,9\% lainnya dipengaruhi oleh faktor lain. Hal ini mendukung pendapat yang dikemukakan oleh Usman dan Setyawati (1993) bahwa lingkungan di sekitar individu seperti, lingkungan keluarga, lingkungan masyarakat, lingkungan akademik, dan lingkungan kelompok memiliki pengaruh terhadap keberhasilan individu dalam belajar. Hasil penelitian ini juga mendukung penelitian sebelumnya antara lain penelitian yang dilakukan oleh Merlyana (1996). Dalam penelitiannya menemukan bahwa ada hubungan yang positif antara faktor dukungan sosial dengan prestasi belajar. Mahasiswa sangat membutuhkan dukungan sosial dari orang-orang di sekitarnya ketika menghadapi masalah dalam studinya.

Berdasarkan hasil penelitian, dapat disimpulkan bahwa self-regulated learning dan persepsi dukungan sosial memiliki hubungan yang positif terhadap prestasi akademik mahasiswa. Semakin tinggi self-regulated learning, maka meningkat prestasi akademik mahasiswa. Semakin tinggi persepsi dukungan sosial, maka meningkat pula prestasi akademik mahasiswa. Besarnya kontribusi yang diberikan self-regulated learning dan persepsi dukungan sosial terhadap prestasi akademik mahasiswa adalah sebesar 18,7\% dan sekitar 81,3\% dipengaruhi oleh faktor-faktor lain yang tidak menjadi fokus penelitian ini. Meskipun kontribusi yang diberikan self-regulated learning dan persepsi dukungan sosial terhadap prestasi akademik mahasiswa relatif sedikit (18,7\%), namun self-regulated learning dan persepsi dukungan sosial tetap memiliki peran sebagai prediktor dalam meningkatkan prestasi akademik mahasiswa. 


\section{Penutup}

Hasil penelitian menunjukkan bahwa variabel self-regulated learning memiliki hubungan yang positif dengan prestasi akademik mahasiswa. Hal ini dapat dilihat berdasarkan hasil analisis regresi bahwa koefisien korelasi antara self-regulated learning dengan prestasi akademik mahasiswa sebesar $\mathrm{r}=0,325, \mathrm{p}<0,001$ (sangat signifikan). Self-regulated learning memberikan sumbangan efektif terhadap prestasi akademik mahasiswa sebesar 0,106 atau 10,6\%. Berdasarkan hasil tersebut, dapat disimpulkan bahwa self-regulated learning secara positif berhubungan dengan prestasi akademik mahasiswa. Semakin tinggi self-regulated learning mahasiswa maka semakin meningkat pula prestasi akademik mahasiswa.

Variabel persepsi dukungan sosial memiliki hubungan yang positif dengan prestasi akademik mahasiswa. Hal ini dapat dilihat berdasarkan hasil analisis regresi bahwa koefisien korelasi antara persepsi dukungan sosial dengan prestasi akademik mahasiswa sebesar $\mathrm{r}=$ 0,284, $\mathrm{p}<0,001$ (sangat signifikan). Persepsi dukungan sosial memberikan sumbangan efektif terhadap prestasi akademik mahasiswa sebesar 0,081 atau 8,1\%. Berdasarkan hasil tersebut, dapat disimpulkan bahwa persepsi dukungan sosial secara positif berhubungan dengan prestasi akademik mahasiswa. Semakin tinggi persepsi dukungan sosial mahasiswa maka semakin meningkat pula prestasi akademik mahasiswa.

Self-regulated learning dan persepsi dukungan sosial memberikan kontribusi terhadap prestasi akademik mahasiswa sebesar 18,7\% dan sekitar $81,3 \%$ dipengaruhi oleh faktor-faktor lain yang tidak menjadi fokus penelitian ini.

\section{DAFTAR PUSTAKA}

Ablard, K.E. \& Lipschultz, R.E. (1998). Self-Regulated Learning in High Achieving Student: Relation to Advanced Reasoning, Achievement Goals, and Gender. Journal of Educational Psychology.

Ancok, J., Faturrachman, \& Sucipto, H.P. (1988). Persepsi Terhadap Kemampuan Kerja Wanita, Jurnal Psikologi. Tahun 6, No. 1 PP., h. 18.

Azwar, S. (2000a). Tes Prestasi, Fungsi dan Pengembangan Pengukuran Prestasi Belajar, Edisi II. Yogyakarta: Pustaka Pelajar.

2000b. Penyusunan Skala Psikologi, Yogyakarta: Pustaka Pelajar.

2000c. Reliabilitas dan Validitas, Yogyakarta: Pustaka Pelajar.

2002. Sikap Manusia, Teori dan Pengukurannya, Edisi II. Yogyakarta: Pustaka Pelajar.

Ahmad, D. (1988). Peranan Perguruan Tinggi Memasuki Era Pembangunan Nasional Abad 21, Prosiding Seminar. Lampung.

Bandura, A. (1977). "Social Learning Theory", http://tip.psychology.org/bandura.html. diakses 20 Oktober 2013.

Baron, R.A. \& Byrne, D. (1991). Social Psychology: Understanding Human Interaction. Boston: Allyn \& Bacon.

Baumeister, R.F. \& Heatherton, T.F. (1996). Self-Regulation Failure: An Onverview. Journal of Psychology Inquiry.

Brehm, S.S. \& Kassin, S.M. (1990). Social Psychology. USA: Houghton Miffin Company. 
Brodjonegoro, S.S., Azra, A., Gaffar, F.M. \& Hidayat, K. (2001). "Implementasi Paradigma Baru di Perguruan Tinggi", dalam Fasli Jalal dan Dedi Supriadi (Editor). Reformasi Pendidikan dalam Konteks Otonomi Daerah, Yogyakarta: Bappenas Depdiknas - Adicita Karya Nusa.

Butler, D. \& Winne, P. (1995). Feedback and Self-Regulated Learning: A Theoretical Synthesis.

Calhoun, F.J. \& Acocella, J.R. (1990). Psikologi Tentang Penyesuaian dan Hubungan Kemanusiaan, Edisi Ketiga. Satmoko, R.S. (Penerjemah) New York: McGraw - Hill.

Chaplin, P.J. (2002). Kamus Lengkap Psikologi, penerjemah: Kartini Kartono. Jakarta: PT. Raja Grafindo Persada.

Cohen, S. \& Syme, S.L. (1985). Social Support and Health, Orlando Florida: Academic Press, Inc. Conger, J.J. (1977). Adolescence and Youth Psychological Development in A Changing World, 2nd editin. New York: Harper and Row.

Crow, L.D. \& Crow, A. (1973). Educational Psychology, Dallas, Francisco: American Book.

Cutrona, C.E., Cole, V., Colangelo, N., Assouline, S.G., \& Russell, D.W. (1994). Perceived Parental Social Support and Academic Achievement: An Attachment Theory Perspective. Journal of Personality and Social Psychology.

Farnsworth, D.L. (1995). Mental Health Implication for Teachers. Dalam Torrance, E. P. and Storm. Mental Reducing School Drop Out, 2nd. New York: R.D. John Wiley Sons, Inc.

Flavell, J.H. (1976). Metacognitive Aspects of Problem Solving. In L.B. Resnick (editor). The Nature of Intelligence, New York: Academic Press.

Ganster, D.C., Fusilier, M.R., \& Mayer, B.T. (1986). Role of Social Support in The Experience of Stress at Work, Journal of Applied Psychology.

Gie, T.L. (1994). Cara Belajar Yang Efisien, Jilid I. Edisi Keempat. Yogyakarta: Liberty. (1995). Cara Belajar Yang Efisien, Jilid II. Edisi Keempat. Yogyakarta: Liberty.

Hadi, S. (2000). Statistik, Jilid 2. Yogyakarta: Andi Offset. (2000). Seri Program Statistik, Manual SPS Paket Midi. Yogyakarta: Andi Offset.

Harvey, J.H. \& Smith, W.P. (1977). Social Psychology, An Attribution Approach, London: The C.V. Mosby Company.

Hergenhann, B.R. \& Olson, M.H. (1997). An Introduction to Theories of Learning, Fifth Edition. New Jersey: Prentice-Hall International, Inc.

Hersen, M. (1987). The Clinical Psychology, Handbook. New York: Zud Printing Pergamon Press. Hurlock, B.E. (2002). Psikologi Perkembangan: Suatu Pendekatan Sepanjang Rentang Kehidupan, Edisi Kelima. Jakarta: Penerbit Erlangga.

Johnson, D.W. \& Johnson, F.P. (1991). Joining Together Group Theory and Group Skills, 4th Edition. USA: Prentice Hall.

Jorgensen, D.L. (1989). Participant Observation A Methodology for Human Studies, India: Sage Publications, Inc.

Jufri, M. (1999). Efikasi Diri, Keterampilan Belajar dan Penyesuaian Diri Sebagai Prediktor Prestasi Akademik Mahasiswa Tahun Pertama, Tesis (tidak diterbitkan) Yogyakarta: Universitas Gadjah Mada.

Juwari, A. (2004). Hubungan antara Tingkat Pendidikan Orangtua, Pola Asub Orang tua dan Motivasi Berprestasi dengan Prestasi Belajar Siswa SMA Negeri di Kulon Progo, Tesis (tidak diterbitkan). 
Yogyakarta: Fakultas Psikologi Universitas Gadjah Mada.

Kerlin, B.A. (2000). Cognitive Engagement Style, Self-Regulated Learning and Cooperative Learning.

Kumara, A. (2000). Kualitas Lulusan Sekolah Lanjutan Tingkat Atas yang Dituntut oleb Perguruan Tinggi yang Kompetitif. Dalam Saifuddin Azwar (Editor) Bunga Rampai Psikologi Pendidikan, Yogyakarta: Pelajar Offset.

Lin, N., Woefel, M.W., \& Light, S.C. (1985). The Buffering of Social Support Subsequent to An Important Live Event, Journal of Health and Social Behavior.

Masrun \& Martaniah, S.M. (1973). Psikologi Pendidikan, Yogyakarta: Yayasan Penerbit Fakultas Psikologi Universitas Gadjah Mada.

Martinez, M. \& Young, B. (1977). Development and Validation of An Intentional Learning Orientation Questionnaire, http://mse.byu.edu/projects/elc/meaprojpr.html (diakses 2 Oktober 2013)

Meichati, S. (1983). Kesehatan Mental, Yogyakarta: Yayasan Penerbitan Fakultas Psikologi Universitas Gadjah Mada.

Merlyana, S. R. (1996). Hubungan Antara Dukungan Sosial, Kepercayaan Diri dan Motif Berprestasi Terhadap Prestasi Belajar Siswa SMU, Skripsi (tidak diterbitkan). Yogyakarta: Fakultas Psikologi Universitas Gadjah Mada.

Miller, D.C. \& Byrnes, J.P. (2001). To Achieve or Not to Achieve: A Self-Regulation Perspective on Adolescent' Academic Decision Making, Journal of Educational Psychology.

Mönks, F.J. \& Ferguson, T.J. (1982). Gifted Adolescents: An Analysis of Their Psychology Development, Journal of Youth and Adolescent. Knoers, A.M.P \& Haditono, S.R. (2002). Psikologi Perkembangan: Pengantar Dalam Berbagai Bagiannya, Yogyakarta: Gadjah Mada University Press.

Mulyani, E.S. (1995). Peranan Inteligensi, Motivasi Berprestasi dan Disiplin Belajar Terbadap Prestasi Belajar Mahasiswa FKIP Universitas Cendrawasih Jayapura Tabun 1994 - 1995, Tesis (tidak diterbitkan) YogyakartaL Universitas Gadjah Mada.

Neuman, W.L. (2000). Social Research Methods, Boston: Allyn and Bacon.

Pearson, R.E. (1990). Counseling and Social Support Perspective and Practice, Newbury Park California: Sage Publications, Inc.

Peverly, S.T., Brobst, K.E., Graham, M., \& Shaw, R. (2003). College Adults Are Not Good at SelfRegulation: A Study on the Relationship of Self-Regulation, Note Taking, and Test Taking, Journal of Educational Psychology.

Purdie, N., Hattie, J., \& Douglas, J. (1996). Student Conceptions of Learning and Their Use of SelfRegulated Learning Strategies: A Cross Cultural Comparison, Journal of Educational Psychology.

Purwanto, P. (2000). Hubungan Self-Regulated Learning dengan Prestasi Belajar, Skripsi (tidak diterbitkan) Yogyakarta: Fakultas Psikologi Universitas Gadjah Mada. (2000). "Self-Regulated Learning: Effective Teaching Techniques for Distance Learning", Rochester Institute of Technology. http://www.rit.edu/ 609www/ch/faculty/ selfreg.htm, diakses 3 Oktober 2013

Ropp, M. 1998. “A New Approach to Supporting Reflective Self Regulated Computer Learning”, http:/ / www.coe.uh.edu/insite/elec_pub/HTML1998/re_ropp.htm, diakses 5 Oktober 2013 
Rose, D. H. \& Winne, P.H. (1993). Measuring Component and Sets of Cognitive Processes in SelfRegulated Learning, Journal of Educational Psychology.

Salisbury-Glennon, J.D., Young, A.J., \& Stefanou, C.R. (2001). Creating Contexts for Motivation and Self-Regulated Learning in The College Classroom. Journal on Excellence in College Teaching.

Sangalang, M.U. (1985). Faktor-faktor yang Mempengarubi Keberbasilan Studi. Dalam Kartini Kartono (Penyunting) Bimbingan Belajar di SMA dan Perguruan Tinggi, Jakarta: CV. Rajawali.

Sarason, I.G., Levine, H.M., \& Basham, R.B. (1983). Assessing Social Support, The Social Support Questionnaire, Journal of Personality and Social Psychology.

Schunk, D.H \& Etmer, P.A. (1999). Self-Regulatory Processes during Computer Skill Acquisition: Goal and Self-Evaluative Influences, Journal of Educational Psychology.

Shu-Shen Shih. (2002). Children's Self Efficacy Beliefs, Goal Setting Behaviors, and Self-Regulated Learning, Journal of National Taipei Teachers College.

Singer, K. (1991). Membina Hasrat Belajar di Sekolah, Bandung: PT. Remaja Rosdakarya.

Slameto. (1995). Belajar dan Faktor-faktor yang Mempengarubinya, Jakarta: PT. Rineka Cipta.

Smet, B. (1994). Psikologi Kesehatan, Jakarta: PT. Grasindo.

Solso, R.L. (1995). Cognitive Psychology, Boston: Allyn and Bacon.

Sternberg, R.J. (1999). Cognitive Psychology, New York: Harcourt Brace College.

Sunawan. (2003). Pengaruh Pengelolaan Diri Terhadap Prestasi Belajar Matematika Siswa SMU, Tesis (tidak diterbitkan) Yogyakarta: Fakultas Psikologi Universitas Gadjah Mada Yogyakarta.

Suryabrata, S. (1990). Proses Belajar-Mengajar di Perguruan Tinggi, Yogyakarta: Andi Offset. (1998). Psikologi Pendidikan, Jakarta: Raja Grafindo Persada.

Suwadji, L. (1985). "Faktor-faktor yang Mempengarubi Keberbasilan Studi” dalam Kartini Kartono (Penyunting), Bimbingan Belajar di SMA dan Perguruan Tinggi, Jakarta: CV. Rajawali.

Syah, M. (2003). Psikologi Belajar, Jakarta: PT. RajaGrafindo Persada.

Taylor, S.E. (1995). Health Psychology, International Edition. Singapore: McGraw-Hill Book Co.

Tim Penyusun Kamus Pusat Pembinaan dan Pengembangan Bahasa. (1989). Kamus Besar Bahasa Indonesia. Jakarta: Balai Pustaka.

Thabrany, H. (1997). Rahasia Sukses Belajar, Jakarta: PT. Raja Grafindo Persada.

Thoits, P.A. (1986). Social Support As Coping Assistance, Journal of Consulting and Clinical Psychology.

Usman, M.U. \& Setyawati, L. (1993). Upaya Optimalisasi Kegiatan Belajar Mengajar, Agus Nasihin (Editor). Bandung: PT. Remaja Rosdakarya.

Viel, H.D.F. \& Baunmann (1992). The Meaning and Measurement of Social Support, New York: Hemisphere Publish Co.

Walgito, B. (1994). Pengantar Psikologi Umum, Yogyakarta: Andi Offset.

Wentzel, K.R. (1994). Relations of Social Goal Persuit to Social Acceptance, Classroom Behavior, and Perceived Social Support, Journal of Educational Psychology.

Winarsunu, T. (2002). Statistik dalam Penelitian Psikologi dan Pendidikan, Malang: UMM Press.

Winkel, W.S. (1996). Psikologi Pengajaran, Jakarta: PT. Grasindo. 
Wirawan, G.Y. (1976). Faktor-Faktor Psikologi yang Berkaitan dengan Perbedaan antara Prestasi dan Kemampuan Para Pelajar SMP D.I. Yogyakarta, Jurnal Psikologi. Yogyakarta: Fakultas Psikologi Universitas Gadjah Mada.

Wisnubrata. (1982). Pengantar Psikologi Belajar, Jakarta: Departemen Pendidikan dan KebudayaanDirektur Jenderal Perguruan Tinggi.

Wolters, C.A. (1998). Self-Regulated Learning and College Students' Regulation of Motivation, Journal of Educational Psychology.

Young, K. (1956). Social Psychology, New York: McGraw-Hill Publisher.

Zimmerman, B.J. (1989). A Social Cognitive View of Self-Regulated Academic Learning, Journal of Educational Psychology.

Zimmerman, B.J. \& Pons, M.M. (1988). Construct Validation of A Strategy Model of Student SelfRegulated Learning, Journal of Educational Psychology. 